\title{
POBLACIONES DE LA GARRAPATA RHIPICEPHALUS (BOOPHILUS) MICROPLUS RESISTENTES A LOS PIRE- TROIDES EN CÓRDOBA Y SALTA, ARGENTINA
}

\author{
Mangold, A. J. ${ }^{1}$, CAstelli, M. e. ${ }^{1}$, NAva, . $^{1}$, \\ AguirRe, D. H. ${ }^{2}$ \& GuglielmoneCHI, A. A. ${ }^{1}$
}

\begin{abstract}
RESUMEN
Desde mayo de 2003 a enero de 2005 se diagnosticó la presencia de cuatro focos de garrapatas Rhipicephalus microplus resistentes a los piretroides (3 en el norte de Córdoba y 1 en Salta). Ello resultó de una combinación de falta de eficacia de los tratamientos a campo y los resultados comparativos con larvas de una colonia susceptible expuestas en papeles de filtro impregnados con dosis crecientes de cipermetrina. Estos resultados evidenciaron concentraciones letales $50\left(\mathrm{CL}_{50}\right)$ superiores al de la colonia susceptible y, en tres casos, falta de superposición en los límites de confianza del $95 \%$. La razón de la resistencia (RR) $\left(\mathrm{CL}_{50}\right.$ incógnita/ $\mathrm{CL}_{50}$ susceptible) varió de $3,1 \mathrm{a}$ 58,7 . En un caso se comparó la $\mathrm{CL}_{50}$ a la flumetrina en relación a la $\mathrm{CL}_{50}$ de una colonia susceptible australiana; la RR alcanzó a 53,3. Estos son los primeros registros de resistencia de $R$. microplus a los piretroides en el noroeste argentino.
\end{abstract}

Palabras clave: Rhipicephalus microplus, resistencia, piretroides, Noroeste Argentino.

\section{SUMMARY}

Population of Rhipicephalus (Boophilus) microplus ticks resistant to pyrethroids in Córdoba and Salta, Argentina.

Four cases of Rhipicephalus microplus ticks resistant to pyrethroids were diagnosed from May 2003 to January 2005 (3 in northern Córdoba, 1 in Salta). Results were based on lack of treatment efficacy under field conditions and comparison of tests with tick larvae from a susceptible pyrethroid colony exposed to filter papers impregnated with cypermethrin. The lethal concentrations $50\left(\mathrm{CL}_{50}\right)$ were higher than the corresponding $\mathrm{CL}_{50}$ of the susceptible colony with no overlap in confidence intervals $95 \%$ in three cases. The resistant ratio $(\mathrm{RR})\left(\mathrm{CL}_{50}\right.$ unknown population/ $\mathrm{CL}_{50}$ susceptible colony) varied from 3.1 to 58.7. The $\mathrm{LC}_{50}$ to flumethrin was obtained in one case and compared with the $\mathrm{LC}_{50}$ of an Australian susceptible colony; the RR was 53.3. These are the first cases of $R$. microplus populations resistant to pyrethroids in northwestern Argentina.

Key words: Rhipicephalus microplus, resistance, pyrethroids, Northwestern Argentina.

1.- INTA EEA Rafaela. C. C. 22. (2300) Rafaela, provincia de Santa Fe.

2.- INTA EEA Salta. C. C. 228. (4400) Salta.

Manuscrito recibido el 19 de abril de 2005 y aceptado para su publicación el 16 de junio de 2005 . 